\title{
Carpometacarpal fracture dislocation of the fourth and fifth finger: mid-term results of 15 patients
}

\author{
Dördüncü ve beşinci parmağın karpometakarpal kırıklı çıkığı: \\ 15 hastanın orta dönem sonuçları
}

\author{
Deniz Gülabi, MD., ${ }^{1}$ Mehmet Ali Uysal, MD., ${ }^{2}$ Bilgehan Çevik, MD., \\ Bülent Kılıç, MD., ${ }^{3}$ Emre Karadeniz, MD. ${ }^{1}$

\begin{abstract}
'Department of Orthopedics and Traumatology, Dr. Lütfi Kırdar Kartal Training and Research Hospital, İstanbul, Turkey ${ }^{2}$ Department of Orthopedics and Traumatology and Hand Surgeon, Dr. Lütfi Kırdar Kartal Training and Research Hospital, İstanbul, Turkey
\end{abstract} \\ ${ }^{3}$ Department of Orthopedics and Traumatology, İstanbul Gelişim University, İstanbul, Turkey
}

\begin{abstract}
Objectives: This study aims to retrospectively evaluate and compare the mid-term clinical follow-up results of patients who were treated with open or closed reduction due to carpometacarpal (CMC) fracture dislocation.

Patients and methods: Medical charts of 15 patients (1 male, 14 females; mean age $32.5 \pm 10.5$ years; range 18 to 55 years) who were operated for fourth and fifth finger CMC fracture dislocations were examined. Patients were divided into two groups according to applied treatment as closed reduction and percutaneous pinning (CRPP, $n=6)$ and open reduction and percutaneous pinning (ORPP, $n=9$ ). Patients were assessed by a hand therapist blinded to the treatment groups. Patients were compared in respect of visual analog scale (VAS), Quick Disabilities of the Arm, Shoulder and Hand (Q-DASH) scores, and grip strength. Complications were recorded.
\end{abstract}

Results: Mean VAS values of ORPP group and CRPP group were $2.33 \pm 0.50$ and $1.67 \pm 0.52$, respectively. Mean Q-DASH values of ORPP group and CRPP group were $13.63 \pm 3.21$ and $9.05 \pm 2.36$, respectively. Mean grip strength values of ORPP group and CRPP group were $65.78 \pm 3.70$ and $75.17 \pm 6.11$, respectively. Mean VAS and Q-DASH scores of ORPP group were statistically significantly higher compared to CRPP group. Mean grip strength value of CRPP group was statistically significantly higher compared to ORPP group.

Conclusion: Treatment of fourth and fifth finger CMC fracture dislocations with CRPP results in statistically superior VAS, Q-DASH and grip strength values in the early post-injury period.

Keywords: Carpometacarpal fracture dislocations; grip strength; hand fractures.
ÖZ

Amaç: Bu çalışmada karpometakarpal (KMK) kırıklı çıkık nedeniyle açık veya kapalı redüksiyon ile tedavi edilen hastaların orta dönem klinik takip sonuçları geriye dönük olarak değerlendirilip karşılaştırıldı.

Hastalar ve yöntemler: Dördüncü ve beşinci parmak KMK kırıklı çıkık nedeniyle ameliyat edilen 15 hastanın (1 erkek, 14 kadın; ort. yaş $32.5 \pm 10.5$ yıl; dağılım 18-55 yıl) tıbbi çizelgeleri incelendi. Hastalar uygulanan tedaviye göre kapalı redüksiyon ve perkütan pinleme (KRPP, n=6) ve açık redüksiyon ve perkütan pinleme (ARPP, n=9) olmak üzere iki gruba ayrıldı. Hastalar tedavi gruplarına kör bir el terapisti tarafından değerlendirildi. Hastalar görsel analog ölçeği (GAÖ), Kol, Omuz ve El Sorunları Hizlı Anketi (Q-DASH) skorları ve yumruk yapma kuvvetine göre karşılaştırıldı. Komplikasyonlar kaydedildi.

Bulgular: ARPP grubu ve KRPP grubunun ortalama GAÖ değerleri sırasiyla $2.33 \pm 0.50$ ve $1.67 \pm 0.52$ idi. ARPP grubu ve KRPP grubunun ortalama Q-DASH değerleri sirasiyla $13.63 \pm 3.21$ ve $9.05 \pm 2.36$ idi. ARPP grubu ve KRPP grubunun ortalama yumruk yapma kuvveti değerleri sırasıyla $65.78 \pm 3.70$ ve $75.17 \pm 6.11$ idi. ARPP grubunun ortalama GAÖ ve Q-DASH skorları KRPP grubuna kıyasla istatistiksel olarak anlamlı şekilde daha yüksekti. KRPP grubunun ortalama yumruk yapma kuvveti değeri ARPP grubuna kıyasla istatistiksel olarak anlamlı şekilde daha yüksekti.

Sonuç: Dördüncü ve beşinci parmak KMK kırıklı çıkıkların KRPP ile tedavisi yaralanma sonrası erken dönemde istatistiksel olarak daha üstün GAÖ, Q-DASH ve yumruk yapma kuvveti değerleri ile sonuçlanmaktadır.

Anahtar sözcükler: Karpometakarpal kırıklı çıkıklar; yumruk yapma kuvveti; el kırıkları.

- Received: January 05, 2017 Accepted: March 24, 2017

- Correspondence: Deniz Gülabi, MD. Kartal Dr. Lütfi Kırdar Eğitim ve Araştırma Hastanesi Ortopedi ve Travmatoloji Kliniği, 34890 Kartal, Istanbul, Turkey. Tel: +90 216 - 4413900 / 1441 e-mail: dgulabi@yahoo.com 
Carpometacarpal (CMC) fracture dislocations of the hand on the ulnar side are relatively rare and have been presented in the literature as case reports or small groups of cases. ${ }^{[1]}$ They represent less than $1 \%$ of all injuries to the hand and wrist regions. ${ }^{[2]}$ Carpometacarpal joint dislocations may result from high-energy trauma, such as motor-vehicle accidents or falls from height, or low-energy trauma, such as fist fights, or a fall on the hand. ${ }^{[2]}$ The ulnar-side CMC joints are less stable due to the shallower, more mobile saddle joint configurations, and looser ligamentous attachments of the two ulnar CMC joints. ${ }^{[3]}$ The fifth CMC joint is the least stable and most commonly dislocated. The diagnosis also can be easily missed. Delayed diagnosis and treatment will usually result in an undesirable outcome of pain, reduced grip strength, and degenerative arthritis. ${ }^{[4]} \mathrm{Up}$ to $43 \%$ of patients with neglected single CMC joint injuries experience residual pain and impaired function. However, with appropriate management, up to $87 \%$ of patients with CMC joint injuries return to full work and sporting activities with negligible pain. ${ }^{[5]}$ The most common clinical sign of the injury is ulnar deviation of the ring and small finger, and tenderness over the CMC joint. ${ }^{[6]}$ Disability of the hand is severe when untreated or in those who received delayed treatment. ${ }^{[5]}$

In this study, we aimed to retrospectively evaluate and compare the mid-term clinical follow-up results of patients who were treated with open or closed reduction due to $\mathrm{CMC}$ fracture dislocation. ${ }^{[7]}$

\section{PATIENTS AND METHODS}

A retrospective analysis was performed on the medical charts of 20 patients who were operated for fourth and fifth finger $\mathrm{CMC}$ fracture dislocations in Kartal Dr. Lütfi Kırdar Training and Research Hospital between May 2011 and May 2014. Of the 20 patients, four were excluded as the radiological images were unsuitable and one was excluded due to insufficient follow-up. Thus, the final study group for evaluation comprised 15 patients ( 1 male, 14 females; mean age $32.5 \pm 10.5$ years; range 18 to 55 years). Patients were divided into two groups according to applied treatment as closed reduction and percutaneous pinning (CRPP, $\mathrm{n}=6$ ) and open reduction and percutaneous pinning (ORPP, $\mathrm{n}=9$ ). Mean ages of patients in the CRPP and ORPP groups were $31.0 \pm 11.5$ years and $33.4 \pm 10.3$ years, respectively (Table I).

All patients were referred to our hand surgery department from other centers. All injuries were the result of an axial load injury (clenched fist injury). The study protocol was approved by the Dr. Lütfi
Kırdar Kartal Training and Research Hospital Ethics Committee. A written informed consent was obtained from each patient. The study was conducted in accordance with the principles of the Declaration of Helsinki.

\section{Surgical technique}

All patients consented to surgery. Firstly, closed reduction was attempted under fluoroscopic imaging. If the reduction was unsatisfactory or unstable, open reduction was the treatment option. Patients were positioned in a supine position, and under axillary anesthesia, closed reduction alone was easily achieved for dislocations of the CMC joints by longitudinal traction and direct pressure over the metacarpal bases. Fixation with Kirschner wire (K-wire) was routinely used to maintain the reduction. After verification of anatomic reduction under fluoroscopic imaging, a below-the-elbow ulnar gutter splint was applied. If open reduction was considered, it was made with a longitudinal dorsoulnar incision, the sensory branches of the ulnar nerve were protected and soft tissue interposition was removed from the fracture side. Following reduction of the dislocation and/or fracture(s), CMC fixation was performed with Kirschner wires (K-wires) and then ligament-capsule repair was performed. The hand was elevated in a bedside sling and active finger movements were encouraged in the early postoperative period. Postoperative recovery was uneventful. The wires were removed at four to six weeks and gentle mobilization was commenced with the help of a hand therapist. Physical therapy was started (Figures 1-3).

\section{Follow-ups}

Patients were recalled to the hand therapy clinic for the final follow-up examination and assessed by a hand therapist blinded to the treatment group. Patients were assessed in respect of visual analog

\section{TABLE}

Distribution of gender and hand dominance in groups

\begin{tabular}{|c|c|c|c|c|c|}
\hline & \multicolumn{2}{|c|}{ ORPP } & \multicolumn{2}{|c|}{ CRPP } & \multirow[b]{2}{*}{$p$} \\
\hline & $\mathrm{n}$ & $\%$ & $\mathrm{n}$ & $\%$ & \\
\hline Gender & & & & & 0.400 \\
\hline Female & 9 & 100 & 5 & 83.3 & \\
\hline Male & 0 & 0 & 1 & 16.7 & \\
\hline Dominant hand & & & & & 1.000 \\
\hline Left & 2 & 22.2 & 2 & 33.3 & \\
\hline Right & 7 & 77.8 & 4 & 66.7 & \\
\hline
\end{tabular}



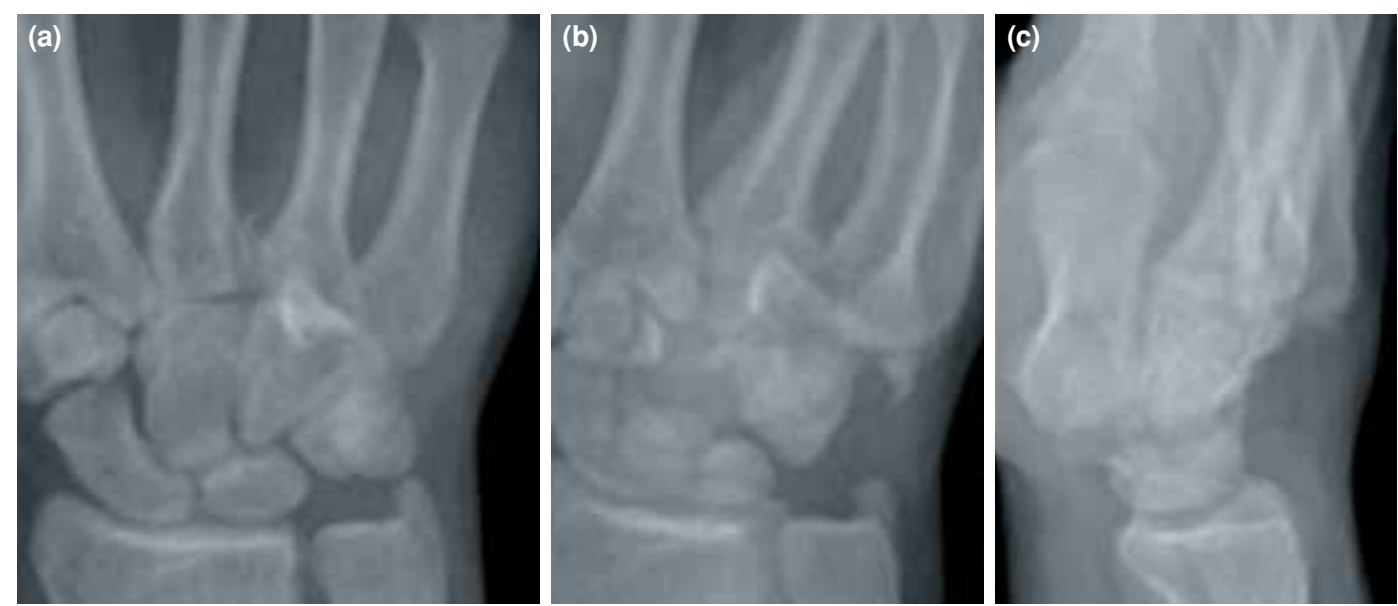

Figure 1. (a-c) A 22-year-old male with fourth and fifth carpometacarpal fracture dislocation of right dominant hand shown on anteroposterior, oblique and lateral radiograms.
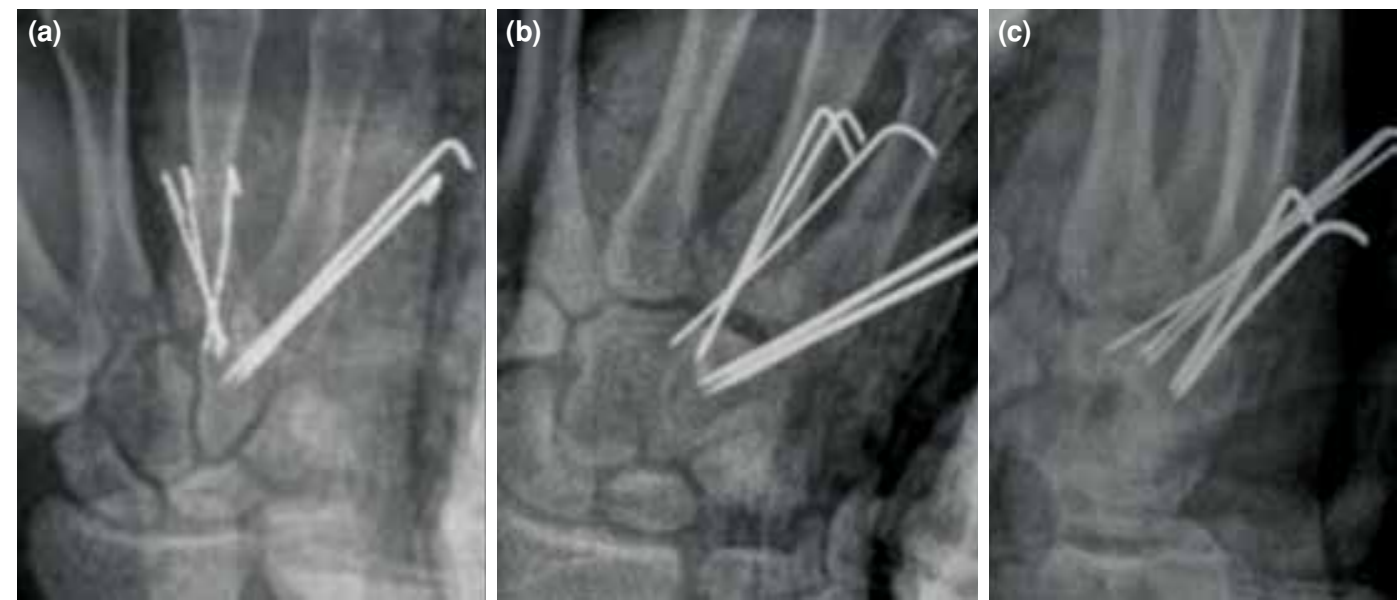

Figure 2. (a-c) After closed reduction and percutaneous pinning, early postoperative anteroposterior, oblique and lateral radiograms of same patient.
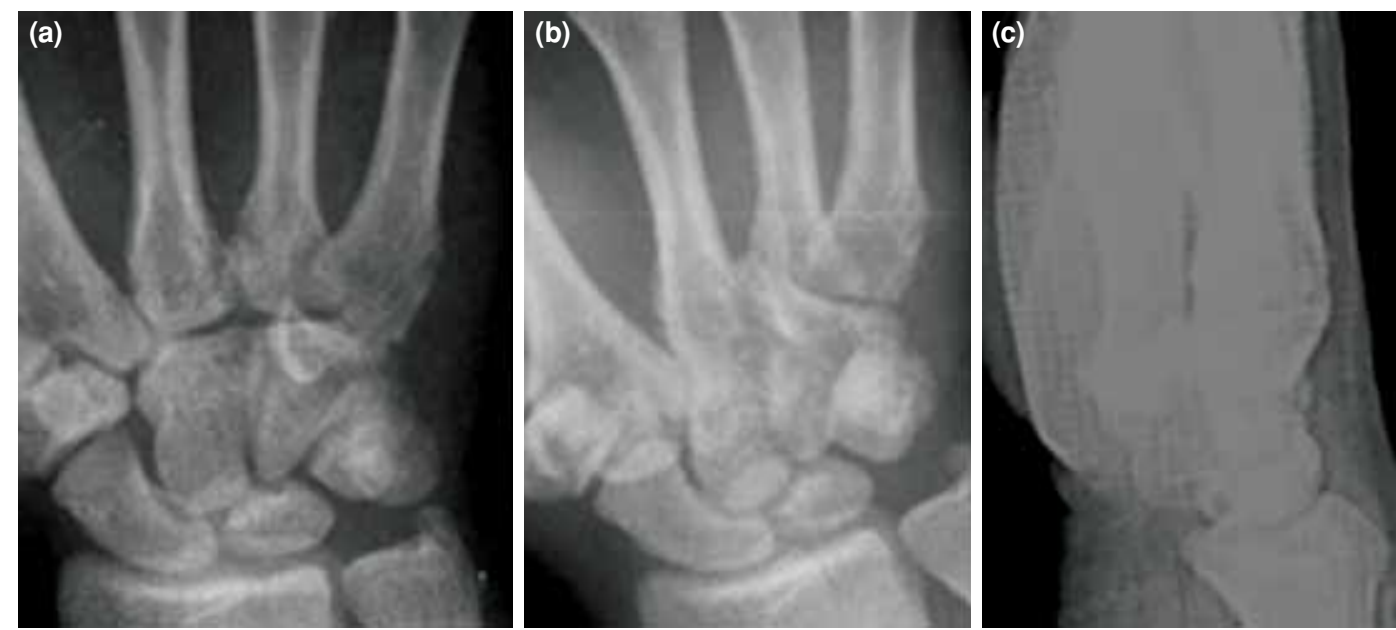

Figure 3. (a-c) Same patient at final follow-up examination in 24 months; anteroposterior, oblique and lateral radiograms. 


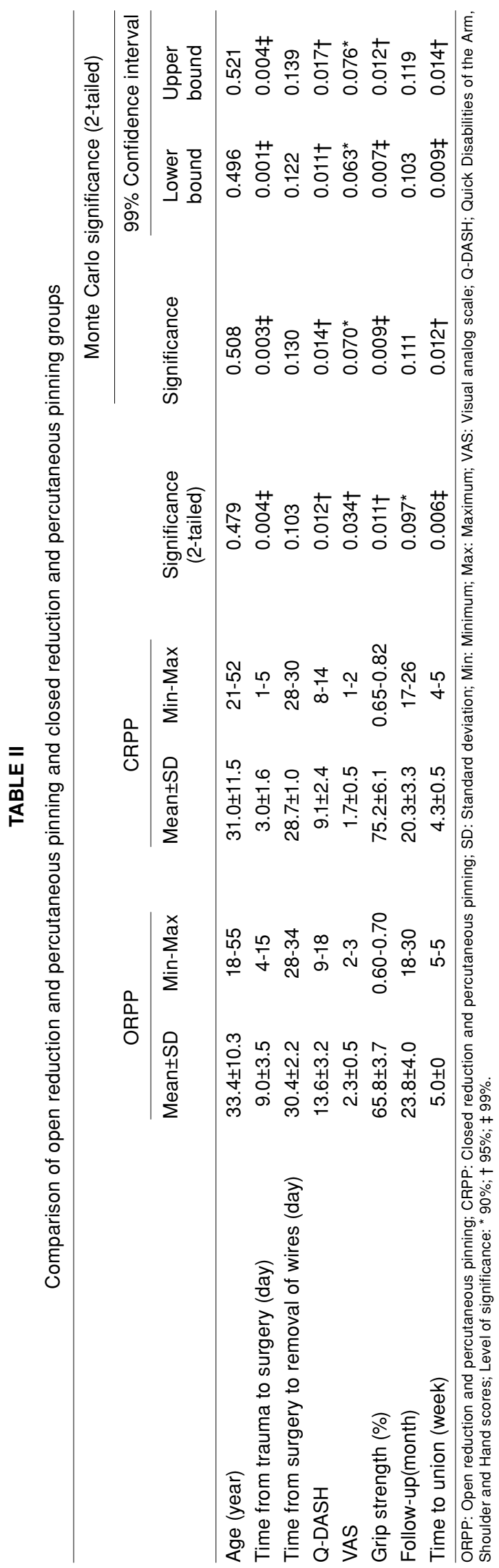

scale (VAS) and Quick Disabilities of the Arm, Shoulder and Hand (Q-DASH) scores. Grip strength was measured on dynamometer and compared with the noninjured hand (Table II). Complications that were noted on the medical charts were also analyzed. The grip strength of the injured hand was calculated as the ratio of grip strength of the injured hand/grip strength of the uninjured hand. The independent observer (hand therapist) assessed all grip strength measurements twice at an interval of 30 minutes. The average of these two measurements were used as the data for evaluation.

\section{Statistical analysis}

All statistical analyses were conducted using SPSS 15.0 software (SPSS Inc., Chicago, IL, USA). Non-parametric Mann-Whitney U test was applied in the comparison of the two groups. Using Monte Carlo simulation on the Mann-Whitney $U$ test results, 10,000 repetitions were performed and a 99\% confidence interval (CI) was calculated for the significance values obtained. When calculating the mean scores and standard deviation $( \pm S D)$ values for both techniques for which the comparison was made, general mean and SD values were calculated for the whole patient group.

\section{RESULTS}

Mean ages of patients in the CRPP and ORPP groups were $31.0 \pm 11.5$ years and $33.4 \pm 10.3$ years, respectively (Table I). No statistically significant difference at a 95\% $\mathrm{CI}$ was determined in respect of the mean age of the patients who underwent ORPP or CRPP $(\mu \mathrm{ORPP}=33.44$; $\mu \mathrm{CRPP}=31.00 ; \mathrm{p}=0.479 ; \mathrm{pMC}=0.508$ ) (Table II).

Mean times from trauma to surgery for the ORPP and CRPP groups were $9.0 \pm 3.5$ days and $3.0 \pm 1.6$ days, respectively. A statistically significant difference at a 99\% CI was determined in respect of the time from trauma to surgery of the patients who underwent ORPP or CRPP $(\mu \mathrm{ORPP}=9.00 ; \mu \mathrm{CRPP}=3.00 ; \mathrm{p}=0.004$; pMC $=0.003$ ) (Table II).

Times from surgery to removal of K-wires for the ORPP and CRPP groups were $30.4 \pm 2.2$ days and $28.7 \pm 1.0$ days, respectively. No statistically significant difference at a $95 \%$ CI was determined in respect of the time from trauma to removal of K-wires of the patients who underwent ORPP or CRPP $(\mu \mathrm{ORPPF}=30.44$; $\mu \mathrm{CRPP}=28.67$; $\mathrm{p}=0.103 ; \mathrm{pMC}=0.130$ ) (Table II).

Mean Q-DASH values for the ORPP and CRPP groups were $13.6 \pm 3.2$ and $9.1 \pm 2.4$, respectively. A statistically significant difference at a $95 \%$ CI was determined in respect of the Q-DASH scores of the patients who underwent ORPP or CRPP 
$(\mu \mathrm{ORPP}=13.63 ; \mu \mathrm{CRPP}=9.05 ; \quad \mathrm{p}=0.012 ; \quad \mathrm{pMC}=0.014)$ (Table II).

Mean VAS values for the ORPP and CRPP groups were $2.3 \pm 0.5$ and $1.7 \pm 0.5$, respectively. According to the Mann-Whitney $\mathrm{U}$ test at a $95 \% \mathrm{CI}$, a statistically significant difference was determined in the mean VAS values of the patients who underwent ORPP or CRPP. According to the simulation results, the difference was at $90 \% \mathrm{CI}(\mu \mathrm{ORPP}=2.33 ; \mu \mathrm{CRPP}=1.67$; $\mathrm{p}=0.034 ; \mathrm{pMC}=0.070$ ) (Table II).

Mean grip strength values for the ORPP and CRPP groups were $65.8 \pm 3.7$ and $75.2 \pm 6.1$, respectively. According to the Mann-Whitney $\mathrm{U}$ test at a $95 \% \mathrm{CI}$, a statistically significant difference was determined in the mean grip strength values of the patients who underwent ORPP or CRPP. According to the simulation results, the difference was at $99 \% \mathrm{CI}$ $(\mu \mathrm{ORPP}=65.78 ; \mu \mathrm{CRPP}=75.17 ; \mathrm{p}=0.011 ; \mathrm{pMC}=0.009)$ (Table II).

Mean follow-up periods for the ORPP and CRPP groups were $23.8 \pm 4.0$ months and $20.3 \pm 3.3$ months, respectively. According to the Mann-Whitney $\mathrm{U}$ test at a $90 \% \mathrm{CI}$, a statistically significant difference was determined in the mean follow-up periods of the patients who underwent ORPP or CRPP. According to the simulation results, there was no significant difference $\mu \mathrm{ORPP}=23.78 ; \mu \mathrm{CRPP}=20.33 ; \quad \mathrm{p}=0.097$; $\mathrm{pMC}=0.111$ (Table II).

Mean time to union for the ORPP and CRPP groups were $5.0 \pm 0$ weeks and $4.3 \pm 0.5$ weeks, respectively. According to the Mann-Whitney U test at a $99 \% \mathrm{CI}$, a statistically significant difference was determined in the mean grip strength values of the patients who underwent ORPP or CRPP. According to the simulation results, the difference was at $95 \%$ CI $(\mu \mathrm{ORPP}=5.00 ; \mu \mathrm{CRPP}=4.33 ; \mathrm{p}=0.006 ; \mathrm{pMC}=0.012)$ (Table II).

One patient in CRPP group and one in ORPP group developed mild pin site infection. One ulnar nerve sensorial neuropraxia developed in ORPP group. Pin site infection was resolved with wet dressings. Ulnar nerve sensorial branch neuropraxia resolved in three months without any treatment.

\section{DISCUSSION}

In this retrospective single center study, patients with fourth and fifth finger CMC fracture dislocations, who were treated with closed reduction and percutaneous pinning or open reduction and percutaneous pinning, were evaluated. Closed reduction and percutaneous pinning group had favorable VAS, Q-DASH and grip strength values compared to the ORPP group.
The mechanism of the injury in this study was fist fights in all patients and was in accordance with the injury mechanisms that have been reported in the literature. Dislocations frequently occur due to a direct force centered at the metacarpal base. Early diagnosis of CMC joint dislocation requires a high index of suspicion based on the mechanism of injury, and detailed clinical examination to identify deformities and neurological deficits that typify such injuries ${ }^{[8]}$ Dorsal dislocations produce a prominent deformity on the dorsal aspect of the hand. ${ }^{[2]}$ Dorsal dislocation of the metacarpals occurs as a result of pull on the extensor carpi ulnaris as its distal insertion is at the base of the fifth metacarpal..$^{[9]}$ Strong dorsal ligaments (compared to volar ones) with additional dynamic support of wrist extensors cause volar ligament rupture. Thus, dorsal dislocations are more frequent than volar ones..$^{[10]}$ Oblique radiographic images with the hand pronated $30^{\circ}$ are mandatory for the diagnosis of this injury. Gillespy et al. ${ }^{[1]]}$ and Takami et al. ${ }^{[12]}$ emphasized that the fragment could be seen on pronation oblique and/or lateral view instead of posteroanterior view. In the present study, oblique radiographs with the hand pronated $30^{\circ}$ were routinely used for diagnosis. Although Andresen et al. ${ }^{[13]}$ and Kaneko et al. ${ }^{[14]}$ demonstrated that threedimension computed tomography (CT) findings proved to be superior to other radiographic imaging, CT imaging is not routinely used in our clinic due to the high cost and radiation exposure.

There was a statistically significant difference between the groups in respect of the time from injury to surgery, with mean $3.0 \pm 1.6$ days calculated for CRPP group and $9.0 \pm 3.5$ days for ORPP group. The delay in the surgery was one of the main causes of open surgery, and poor results. The delay in surgery for the ORPP group was a result of delayed diagnosis because all the cases were initially missed. Studies by Henderson and Arafa, ${ }^{[6]}$ Lawlis and Gunther ${ }^{[5]}$ and Pullen et al. ${ }^{[15]}$ noted that most injuries were initially missed, and were missed in a primary care or emergency setting due to the complexity of reading lateral hand radiographs. Clinical suspicion and the use of appropriate radiological examination methods, especially oblique radiographs in pronation, may prevent the overlooking of this rare injury. Some authors have recommended adding a $30^{\circ}-45^{\circ}$ pronation oblique image to evaluate ring and small CMC joint injuries following axial load injuries. ${ }^{[9,16]}$

There was a significant difference between the groups with respect to the grip strength. The grip strength was more powerful in the CRPP group. We think that this could be related to the open surgery 
that may have resulted in soft tissue impairment and adhesions. Weakness of power grip has been well documented ${ }^{[17-19]}$ and is thought to be due to a decreased range of movement of the fifth metacarpal base. ${ }^{[19]}$ Strapczynski et al. ${ }^{[17]}$ suggested that an additional causative factor was slight rotation of the fragments at the metacarpal base. Weakness is very important for manual workers and may result in a major residual functional disability after inadequate reduction of the injury.

A comparison between the two groups revealed a significant difference, with more favorable VAS and Q-DASH results in the CRPP group. This can be considered to be the result of delayed surgery due to the initial missed diagnosis as stated by Imbriglia. ${ }^{[4]}$ Also, open surgery may have disturbed the soft tissue and resulted in adhesions and soft tissue impairments. The favorable results in the CRPP group may also be considered to be the result of the impairment of tendon gliding in the ORPP group as reported by Gunther. ${ }^{[20]}$ However, in studies by Bora and Didizian ${ }^{[9]}$ and Pullen et al., ${ }^{[15]}$ it was reported that satisfactory grip strength was maintained after closed reduction and open reduction treatment modalities, although no objective measurement of grip strength was available in those older studies. For this purpose, we used the dynamometer to investigate any statistically significant differences between the groups.

Complications after surgical treatment of CMC fracture dislocations have been reported as pain, uncomfortable pinching, superficial or deep infection, arthrosis, ulnar nerve sensorial lesion, scar formation, and pin site infection. In the present study, one patient in both the CRPP and ORPP groups developed stage 1 pin-site infection as described by Dahl et al. ${ }^{[21]}$ and both cases were resolved with wet dressings. One patient in the ORPP group developed ulnar nerve sensorial branch neuropraxia which resolved in three months without treatment. Pullen et al. ${ }^{[15]}$ reported one case with degenerative arthrosis as a result of intra-articular fracture. In the present study, degenerative arthrosis was not determined in any cases; this could be related to the short-term followups. When anatomical reduction is achieved, arthrosis would be avoided but it can also be considered that the follow-up period of the current study was too short to identify degenerative arthrosis.

Limitations of our study include the inability to perform an a priori power analysis, given the lack of previous background data. The retrospective nature of the study, the low number of cases, and short follow-up periods were other limitations.
In conclusion, treating fourth and fifth finger CMC fracture dislocations with CRPP in the early post-injury period resulted in statistically favorable VAS, Q-DASH and grip strength values. However, further prospective randomized level 1 multicenter studies are required to establish clinical relevance.

\section{Declaration of conflicting interests}

The authors declared no conflicts of interest with respect to the authorship and/or publication of this article.

\section{Funding}

The authors received no financial support for the research and/or authorship of this article.

\section{REFERENCES}

1. Hsu JD, Curtis RM. Carpometacarpal dislocations on the ulnar side of the hand. J Bone Joint Surg [Am] 1970;52:927-30.

2. Gurland M. Carpometacarpal joint injuries of the fingers. Hand Clin 1992;8:733-44.

3. Gunther SF, Bruno PD. Divergent dislocation of the carpometacarpal joints: a case report. J Hand Surg Am 1985;10:197-201.

4. Imbriglia JE. Chronic dorsal carpometacarpal dislocation of the index, middle, ring, and little fingers: a case report. J Hand Surg Am 1979;4:343-5.

5. Lawlis JF, Gunther SF. Carpometacarpal dislocations. Longterm follow-up. J Bone Joint Surg [Am] 1991;73:52-9.

6. Henderson JJ, Arafa MA. Carpometacarpal dislocation. An easily missed diagnosis. J Bone Joint Surg [Br] 1987;69:212-4.

7. Atik OŞ. Do we surgeons perform surgery only? Eklem Hastalik Cerrahisi 2016;27:123-4.

8. Woon CYL, Chong KC, Low CO. Carpometacarpal joint dislocations of the index to small finger: three cases and a review of the literature. Injury Extra 2006;37:466-72.

9. Bora FW Jr, Didizian NH. The treatment of injuries to the carpometacarpal joint of the little finger. J Bone Joint Surg [Am] 1974;56:1459-63.

10. Yadav V, Marya KM. Divergent multiple carpometacarpal fracture dislocation; J Orthopaed Traumatol 2002;3:113-5.

11. Gillespy T, Stork JJ, Dell PC. Dorsal fracture of the hamate: distinctive radiographic appearance. AJR Am J Roentgenol 1988;151:351-3.

12. Takami H, Takahashi S, Hiraki S. Coronal fracture of the body of the hamate: case reports. J Trauma 1992;32:110-2.

13. Andresen R, Radmer S, Sparmann M, Bogusch G, Banzer D. Imaging of hamate bone fractures in conventional X-rays and high-resolution computed tomography. An in vitro study. Invest Radiol 1999;34:46-50.

14. Kaneko K, Ono A, Uta S, Mogami A, Shimamura Y, Iwase $\mathrm{H}$, Kurosawa $\mathrm{H}$. Hamatometacarpal fracturedislocation: distinctive three dimensional computed tomographic appearance. Chir Main 2002;21:41-5.

15. Pullen C, Richardson M, McCullough K, Jarvis R. Injuries to the ulnar carpometacarpal region: are they being underdiagnosed? Aust N Z J Surg 1995;65:257-61.

16. Cain JE Jr, Shepler TR, Wilson MR. Hamatometacarpal fracture-dislocation: classification and treatment. J Hand Surg Am 1987;12:762-7. 
17. Stapczynski JS. Fracture of the base of the little finger metacarpal: importance of the "ball-catcher" radiographic view. J Emerg Med 1991;9:145-9.

18. Fisher MR, Rogers LF, Hendrix RW. Systematic approach to identifying fourth and fifth carpometacarpal joint dislocations. JR Am J Roentgenol 1983;140:319-24.
19. Dommisse IG, Lloyd GJ. Injuries to the fifth carpometacarpal region. Can J Surg 1979;22:240-4.

20. Gunther SF. The carpometacarpal joints. Orthop Clin North Am 1984;15:259-77.

21. Dahl MT, Gulli B, Berg T. Complications of limb lengthening. A learning curve. Clin Orthop Relat Res 1994;301:10-8. 